\title{
Some species of the genus Neocyprideis in the early Tertiary of Pakistan
}

\author{
QADEER A. SIDDIQUI \\ Department of Geology, Saint Mary's University, Halifax, Nova Scotia, Canada B3H 3C3
}

\begin{abstract}
Four species of the genus Neocyprideis described in this paper are an addition to the ostracod fauna from the early Tertiary of Pakistan. $N$. sp. A occurs in the Upper Palaeocene of the Sor Range, and three new species are found in the Eocene of the Sulaiman Range. The new species are Neocyprideis simplex and $N$. regularis from the upper Lower Eocene, and $N$. formosa from the uppermost Eocene. The first two species, the associated ostracod fauna and the lithology suggest a shallow marine shelf environment with evaporitic conditions, while $N$. formosa lived in an open marine shelf environment. The short vertical ranges of these three new species makes them useful stratigraphic markers in this area. $J$. Micropalaeontol. 19(1): 1-7, May 2000
\end{abstract}

\section{INTRODUCTION}

Neocyprideis was established as a subgenus of Cyprideis by Apostolescu in 1956, based upon Cyprideis (Neocyprideis) durocortoriensis from the Upper Palaeocene of the Paris Basin as the type species. It was raised to generic status (by Moore 1961, p. Q277) and van Morkhoven (1963, p. 294). Neocyprideis differs from Cyprideis in having a less complex hinge, fewer radial pore canals, less pronounced sexual dimorphism and in having a less rounded outline in lateral view (van Morkhoven, 1963, p. 295).

The known stratigraphic range of Neocyprideis is late Cretaceous to early Miocene, while Cyprideis ranges from Miocene to Recent. Neocyprideis was a widely distributed genus in the Palaeogene, and has been reported from western and southern Europe, Turkey, Israel, Oman, Pakistan and West Africa (Keen \& Racey, 1991).

The four species from Palaeogene sediments that are described in this paper were referred to as Neocyprideis sp. A, B, C, and D in Siddiqui (1971). N. sp. A occurs in the Upper Palaeocene and is left in open nomenclature; the other three are new species. N. simplex (sp. B) and N. regularis (sp. C) are found in the Shales with Alabaster, upper Lower Eocene, and $N$. formosa (sp. D) is found in the Upper Chocolate Clays (upper part), uppermost Eocene. Eocene outcrops in the northwest of Pakistan are shown in Fig. 1. The stratigraphic distribution of Neocyprideis species in the Sor and Sulaiman ranges is shown in Fig. 2.

This paper deals with a small part of the Early Tertiary ostracod fauna from three river sections in Pakistan (Fig. 1). About half of this material has already been described by Siddiqui (1971, 1981), and Siddiqui \& Al-Furaih (1981). The specimens have been deposited in the Natural History Museum, London.

Terminology used here for the rock units of the Eocene succession of the Rakhi Nala, and which also occur in the northern part of the Sulaiman Range, is that published by Siddiqui (1971, modified from Eames 1952). These units are easily distinguished on the basis of lithology and microfauna.

\section{SYSTEMATIC DESCRIPTIONS}

Subclass Ostracoda Latreille, 1806

Order Podocopida Muller, 1894

Suborder Podocopina Sars, 1866

Superfamily Cytheracea Baird, 1850
Family Cytherideidae Sars, 1925

Subfamily Cytherideinae Sars, 1925

Genus Neocyprideis Apostolescu, 1956

Neocyprideis sp. A

(Pl. 1, fig. 1)

Figured specimen. Carapace, male; OS 14878.

Material. One specimen from the Sor Range section from one horizon (Sample no. 460c).

Locality and horizon. Sor Range section, eight miles east of Quetta. Upper Palaeocene.

Description. Carapace sub-rectangular in lateral outline. Anterior and posterior margins broadly rounded, dorsal margin almost straight, ventral margin slightly incurved in the middle. Greatest height at the posterior cardinal angle. Left valve larger than the right valve. Shell surface coarsely punctate with a short sulcus in the antero-dorsal region. Internal details not seen.

Dimensions ( $\mu \mathrm{m})$. Length, 599; height, 406; width, 286.

Remarks. A single carapace was found in the Upper Palaeocene of the Sor Range section and so the species is left in open nomenclature.

\section{Neocyprideis simplex sp. nov.}

(P1. 1, figs. 2-7)

Derivation of name. Latin simplex, simple; with reference to shape of carapace.

Diagnosis. A species belonging to the genus Neocyprideis with dorsal margin almost straight in right valve but slightly convex upwards in left valve, the male dimorph distinct in dorsal view with pointed anterior and posterior ends.

Holotype. OS 14881, female carapace, ( $\mathrm{Pl} \mathrm{1,} \mathrm{fig.} \mathrm{4).}$

Paratypes. OS 14879, OS 14880, OS 14882-4.

Material. Three hundred and thirty-one specimens from the Rakhi Nala section, from eight horizons (sample nos. 3448, 3450 to $3454,3456,3460$, and 3461 ). Seventy-six specimens from the Zao River section from two horizons (sample nos. 24107 and 24110). Sixty-one specimens from the Shpalai Khwara section from two horizons (samples nos. 24683 and 24686).

Type locality and horizon. Rakhi Nala section, Sulaiman Range. Shales with Alabaster, uppermost unit of the Ghazij Formation, upper Lower Eocene.

Description. Carapace sub-rectangular to sub-oval in lateral 


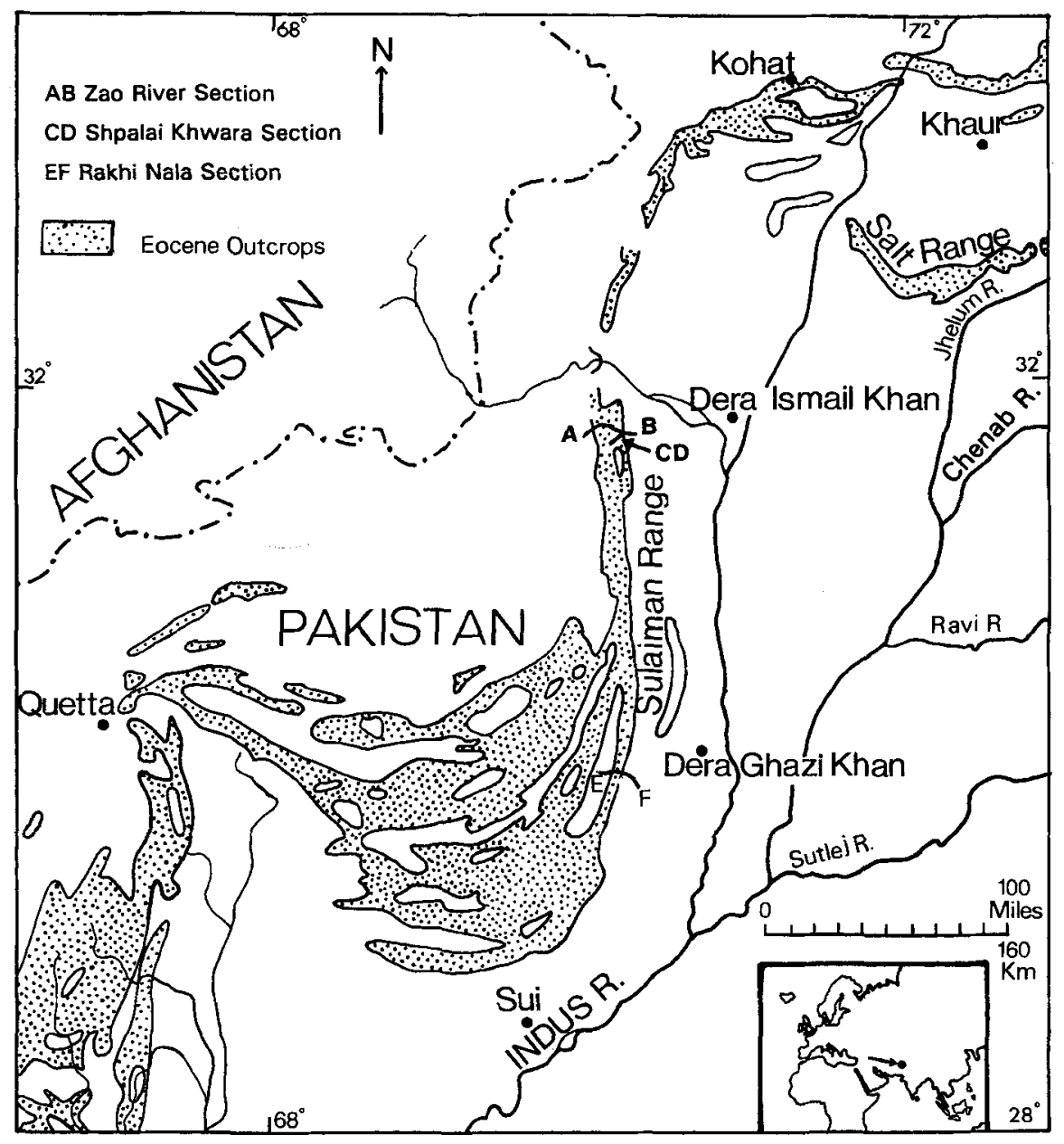

Fig. 1. Outcrops of Eocene rocks of part of Pakistan (after Eames, 1952).

outline. Sexual dimorphism distinct; the male dimorphs are more elongate, less high and less wide than the females. Both anterior and posterior margins broadly and obliquely rounded. Dorsal margin almost straight in the right valve but slightly convex upwards in the left valve. Greatest height at the anterior cardinal angle. Left valve larger than the right, over-reaching it at almost all the margins. In dorsal view the male and female dimorphs are quite distinct; in the male both anterior and posterior ends are pointed while in the female only the anterior end is pointed. Surface ornamentation variable, smooth, pitted or punctate. Internal details not seen.

Dimensions $(\mu \mathrm{m})$ :

\begin{tabular}{llll}
\hline & L & H & W \\
\cline { 1 - 3 } Holotype, female carapace, OS 14881 & 747 & 452 & 378 \\
Paratype, male carapace, OS 14879 & 692 & 415 & 332 \\
Paratype, male carapace, OS 14880 & 710 & 415 & 336 \\
Paratype, male carapace, OS 14882 & 747 & 470 & 369 \\
Paratype, female carapace, OS 14883 & 775 & 507 & 424 \\
Paratype, female carapace, OS 14884 & 747 & 470 & 406 \\
\hline
\end{tabular}

Remarks. The present species shows some resemblance to Neocyprideis bhupendri (Singh \& Misra 1968) in Khosia (1972 pl. 1, fig. 15) but differs from it in being larger and having a less tapered carapace towards the posterior. This species occurs only in the Shales with Alabaster, uppermost unit of the Ghazij Formation, upper Lower Eocene of the Rakhi Nala, Zao River and Shpalai Khwara sections of the Sulaiman Range.

Neocyprideis regularis sp. nov. (Pl. 1, figs 8-10; Pl. 2, figs 1, 2)

Derivation of name. Latin regularis, according to rule; with reference to subovate carapace, a shape common in many species of this genus.

Diagnosis. A large species of Neocyprideis with nearly smooth shell surface with scattered pits (punctae in juveniles); a weak, almost vertical, sulcus in the anterior third, anterior broadly and obliquely rounded towards the anteroventral margin, posterior margin broadly and obliquely rounded towards the posterodorsal margin.

Holotype. OS 14887, female carapace (Pl. 1, fig. 10).

Paratypes. OS 14885, OS 14886, OS 14888, OS 14889. 


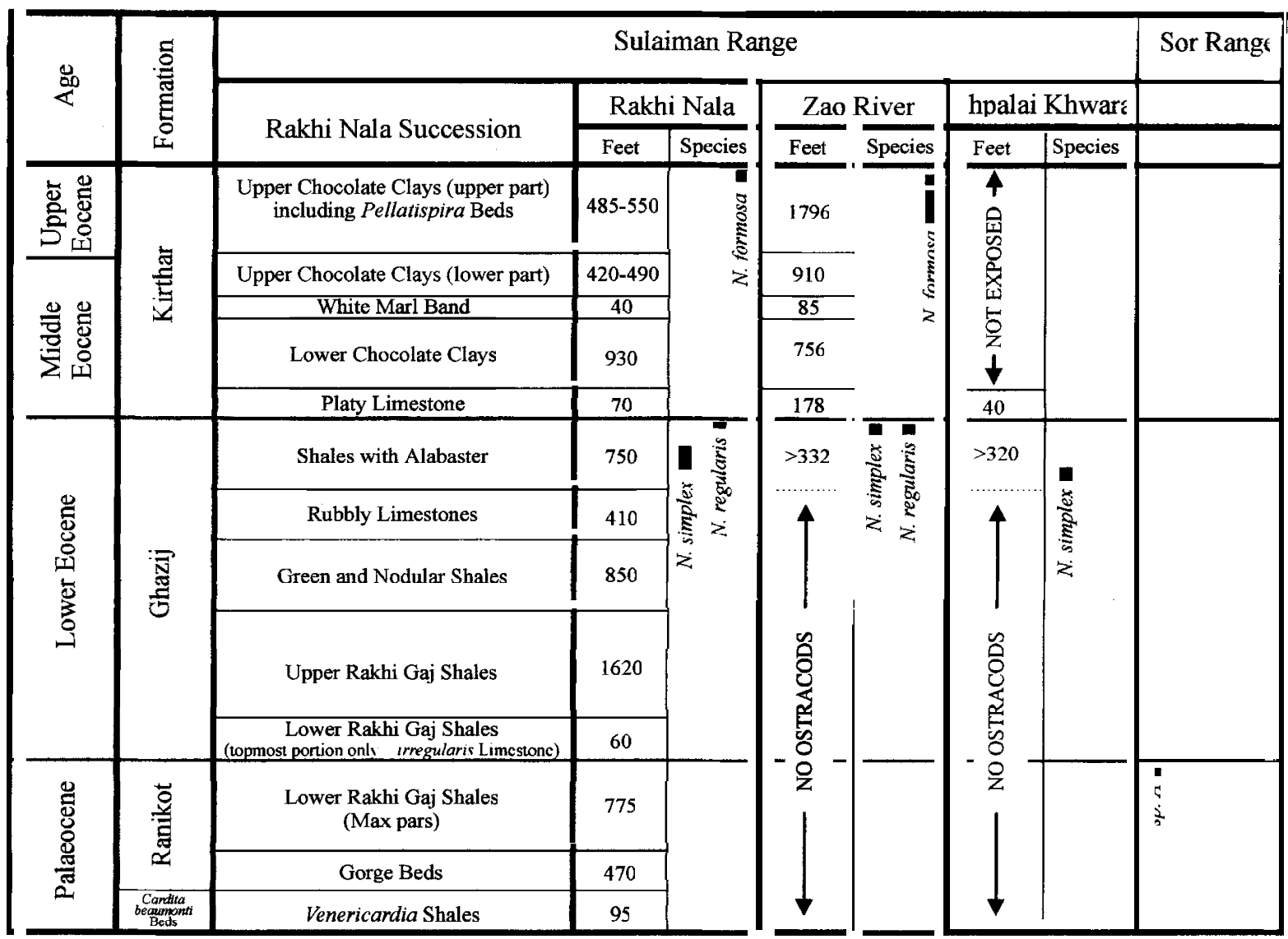

Fig. 2. Stratigraphic distribution of Neocyprideis species in the Palaeocene and Eocene of Pakistan.

Material. Fifty-six specimens from the Rakhi Nala section from one horizon (sample no. 3473). Thirty-five specimens from the Zao River section from two horizons (sample nos. 24107 and 24110).

Type locality and horizon. Rakhi Nala section, Sulaiman Range. Shales with Alabaster, uppermost member of the Ghazij Formation, upper Lower Eocene.

Description. Carapace suboval in lateral outline. Sexual dimorphism well developed, the female dimorphs proportionally less elongate, more high and more wide than the males. Anterior margin broadly and obliquely rounded towards the posterodorsal margin; dorsal and ventral margins subparallel, almost straight in left valve but slightly incurved in the right valve. In dorsal view, carapace is arrow-shaped with maximum width posterior to the middle. Anterior and posterior cardinal angles rounded. Greatest height in the posterior fourth of the carapace. Left valve larger than the right and over-reaching it at the anteroventral, posteroventral, posterior and ventral margins. Shell surface almost smooth with scattered pits (punctate in juveniles) and a weak almost vertical sulcus in the anterior third. Hinge-hemimerodont: left valve with anterior element a long loculate groove, median element with a loculate bar and posterior element with a short loculate groove; right valve complementary. Left valve with an accommodation groove above the median bar. Duplicature of moderate width with a well-marked selvage groove in the posterior region of the left valve. Radial pore canals simple, straight, about 20 anteriorly. Normal pores sieve-type. Muscle scars not clearly seen but appear to consist of four adductors in a subvertical column, frontal and mandibular muscle scars obscure.

Dimensions $(\mu m)$.

\begin{tabular}{llll}
\hline & L & H & W \\
\hline Holotype, female carapace, OS 14887 & 830 & 507 & 424 \\
Paratype, male carapace, OS 14885 & 775 & 479 & 369 \\
Paratype, male carapace, OS 14886 & 867 & 507 & 369 \\
Paratype, female left valve, OS 14889 & 756 & 461 & \\
Paratype, female right valve, OS 14889 & 775 & 480 & \\
\hline
\end{tabular}

Remarks. Neocyprideis rusaylensis Keen \& Racey (1991, p. 230, pl. 1, figs 7-15) is a closely related species. These two species, however, can be separated by differences in lateral outline, particularly in the female dimorph. Both anterior and posterior margins are more obliquely rounded towards the venter in $N$. rusaylensis. These two species also differ in dorsal view, the male of the present species having a more rouded posterior. Both Neocyprideis cf. apostolescui (Keij, 1957) and Neocyprideis 


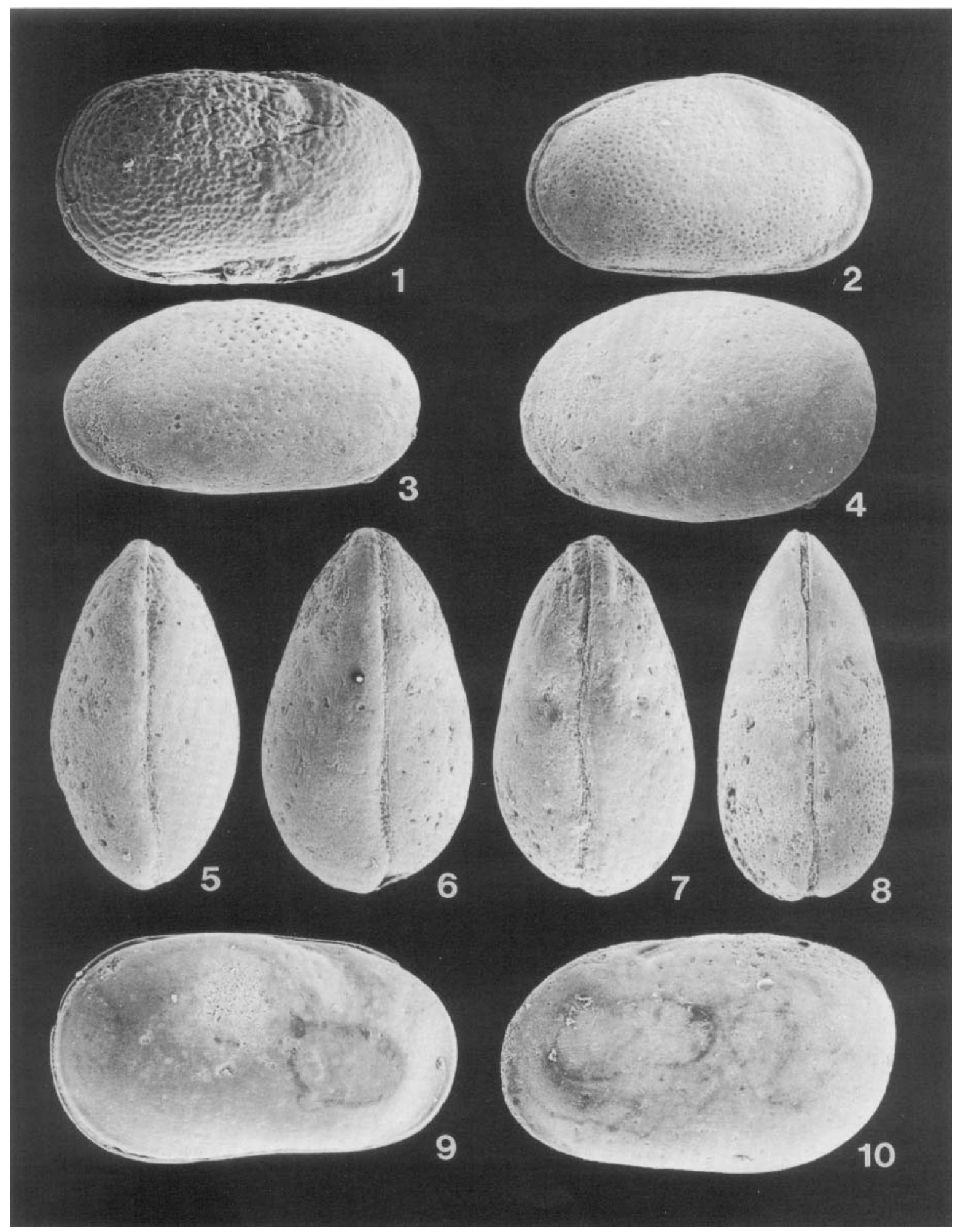

Explanation of Plate 1

fig. 1, Neocyprideis species A, Upper Palaeocene, Sor Range. OS 14878; carapace, right lateral view, $\times 100$. figs 2-7, Neocyprideis simplex sp. nov. Shales with Alabaster, upper Lower Eocene, Rakhi Nala. fig. 2, paratype, OS 14879; carapace, male, right lateral view, $\times 83$. fig. 3, paratype, OS 14880; carapace, male, left lateral view, $\times 83$. fig. 4, holotype, OS 14881; carapace, female, left lateral view, $\times 79$. fig. 5, paratype, OS 14882; carapace, male, dorsal view, $\times 78$. fig. 6, paratype, OS 14883; carapace, female, dorsal view, $\times 78$. fig. 7, paratype, OS 14884; carapace, female, ventral view, $\times 81$. figs 8-10, Neocyprideis regularis sp. nov. Shales with Alabaster, upper Lower Eocene, Rakhi Nala. fig. 8, paratype, OS 14885; carapace, male, dorsal view, $\times 79$. fig. 9, paratype, OS 14886; carapace, male, right lateral view, $\times 79$. fig. 10, holotype OS 14887; carapace, female, left lateral view, $\times 79$. 

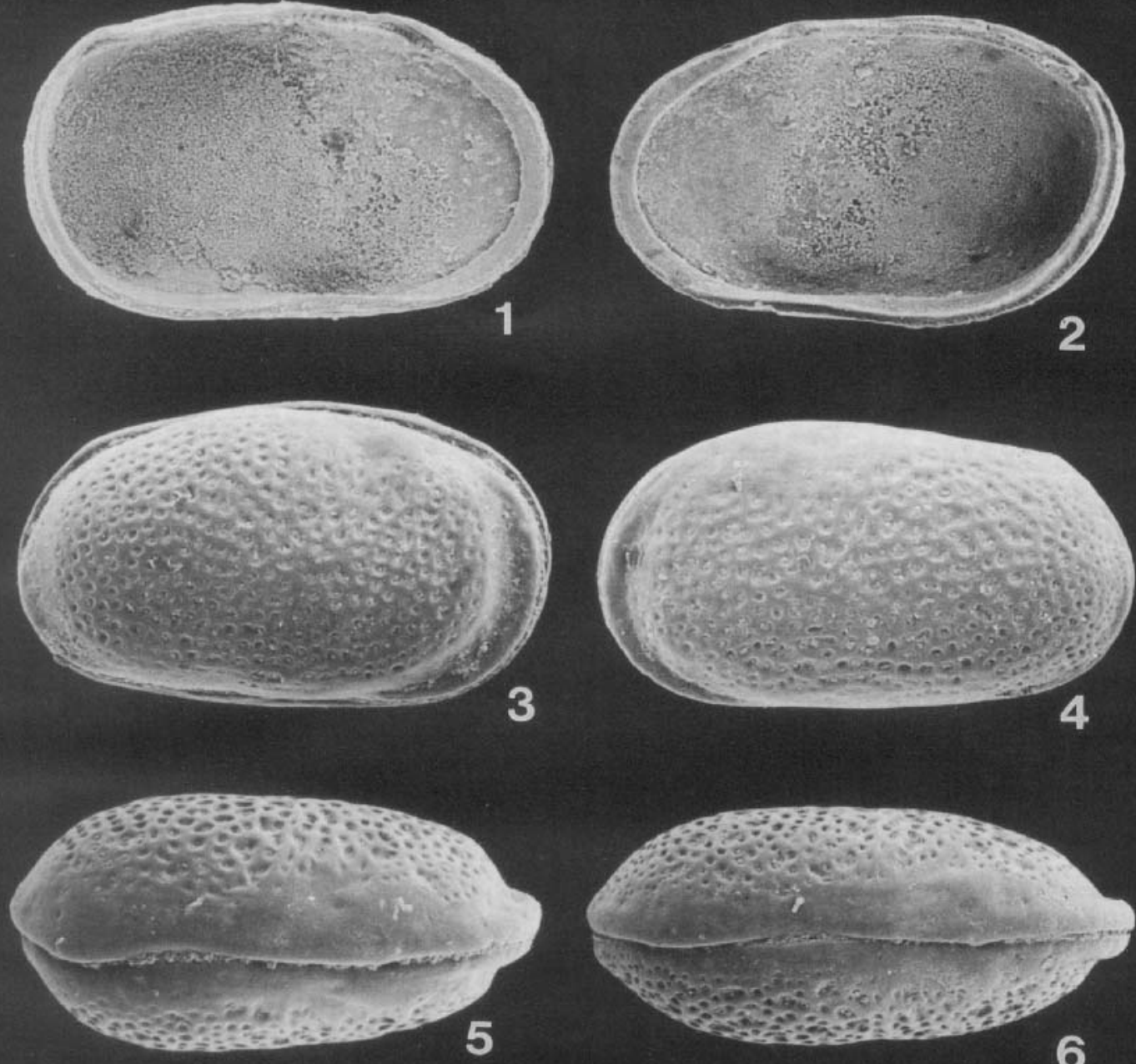

6
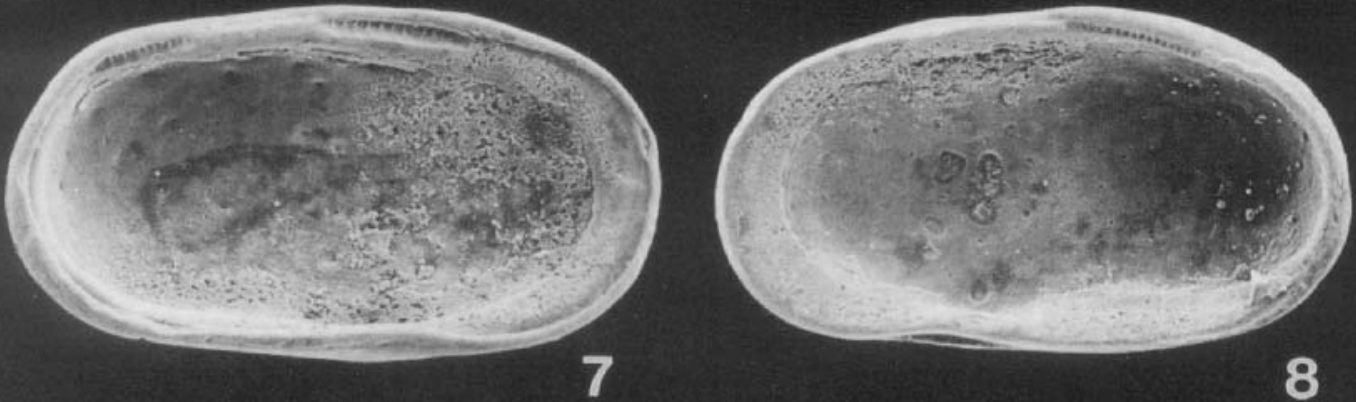

\section{Explanation of Plate 2}

figs 1, 2. Neocyprideis regularis sp. nov. Shales with Alabaster, upper Lower Eocene, Rakhi Nala. fig. 1, paratype, OS14888; left valve, female, internal, lateral view, $\times 82$. fig. 2, paratype, OS 14889; right valve, female, internal, lateral view, $\times 80$. figs 3-8, Neocyprideis formosa sp. nov. Upper Chocolate Clays (upper part), uppermost Eocene, Rakhi Nala. fig. 3, holotype, OS 14890; carapace, female, right lateral view, $\times 76$. fig. 4, paratype, OS 14891; carapace, male, left lateral view, $\times 77$. fig. 5, paratype, OS 14892; carapace, female, dorsal view, $\times 80$. fig. 6, paratype, OS 14893; carapace, male, dorsal view, $\times 81$. fig. 7, paratype, OS 14894 ; left valve, female, internal view, $\times 82$. fig. 8, paratype, OS 14895 ; right valve, female, internal view, $\times 81$. 
williamsoniana (Bosquet, 1852) as illustrated in 'Atlas des Ostracodes de France', Oertli (1985, pl. 75, figs 2, 5) show some resemblance to the present species but differ in lateral outline. Neocyprideis colwellensis (Jones, 1857) (Keen, 1990, P1. 2) differs from the present species in lateral outline and surface ornamentation.

This species only occurs in the upper part of the Shale with Alabaster, uppermost member of the Ghajiz Formation, upper Lower Eocene of the Rakhi Nala and Zao River sections.

\section{Neocyprideis formosa sp. nov.}

(Pl. 2, figs 3-8)

Derivation of name. Latin formosus, beautifully formed; with reference to surface ornamentation.

Diagnosis. A species of the genus Neocyprideis with reticulate surface ornamentation except on the dorsal surface; a depression between anterior marginal rim and anterior platform; anterior duplicature fairly wide.

Holotype. OS 14890, female carapace ( $\mathrm{Pl}$ 2, fig. 3).

Paratypes. OS 14891-5.

Material. Four hundred and thirty-nine specimens from the Rakhi Nala section from three horizons (sample nos. 3658, 3663 and 3664). Two hundred and thirty-four specimens from the Zao River section from six horizons (sample nos. 24170,24180 and 24183, 24191, 24193 and 24195).

Type locality and horizon. Rakhi Nala section, Sulaiman Range. Pellatispira beds, Kirthar Formatiom, uppermost Eocene.

Description. Sexual dimorphism apparent; the males are more elongate and less wide than the females. Carapace subrectangular in lateral outline with dorsal and ventral margins sub-parallel. Anterior cardinal angle rounded in both valves, but posterior cardinal angle obtuse in left valve and rounded in right valve. Greatest height is at the anterior third of the carapace. Left valve larger than the right valve and over-reaching it at the anterodorsal and posteroventral margins. Shell surface reticulate with rounded fossae; an indistinct sulcus between anterodorsal and mid-dorsal area. Anterior marginal rim distinct with a wellmarked depression posteriorly. Hinge hemi-merodont: left valve with anterior element a loculate groove, median element a loculate bar and posterior element a loculate groove (anterior groove almost twice the length of posterior groove). Right valve complementary. Anterior and ventral duplicature fairly wide with a well-marked subperipheral selvage. Radial pore canals not seen. Normal pores sieve type. Muscle scars consist of a subvertical row of four adductors, a V-shaped frontal scar opening towards the anteroventral margin and an oval-shaped mandibular scar.

Dimensions $(\mu \mathrm{m})$.

\begin{tabular}{llll}
\hline & L & H & W \\
\hline Holotype, female carapace, OS 14890 & 830 & 470 & 369 \\
Paratype, male carapace, OS 14891 & 830 & 443 & 323 \\
Paratype, female carapace, OS 14892 & 793 & 443 & 369 \\
Paratype, male carapace, OS 14893 & 793 & 443 & 323 \\
Paratype, female left valve, OS 14894 & 775 & 424 & \\
Paratype, female right valve, OS 14895 & 775 & 415 & \\
\hline
\end{tabular}

Remarks. The present species shows some resemblance to Miocyprideis paravurensis Khosla 1988 from the Lower Miocene of Kerala, but differs from it in lateral outline and in having a well-marked postero-cardinal angle in the left valve. Miocyprideis fortisensis fortisensis (Keij, 1955) from the Lower Miocene of Moulin de Fortis (Bazadais), as illustrated in 'Atlas des Ostracodes de France' (Oertli, 1985, pl. 91, figs 5, 6), shows some affinity with Neocyprideis formosa sp. nov., but differs from it in having a less pronounced posterocardinal angle in the left valve and a less well-developed anterior marginal rim. This species occurs in the upper part of the Upper Chocolate Clays in both the Rakhi Nala and Zao River sections.

\section{PALAEOECOLOGY}

Neocyprideis is closely related to the modern genus Cyprideis, species of which are typically found in brackish to hypersaline waters and some of which develop hollow tubercles in waters of low salinity. Neocyprideis species have also been interpreted as inhabiting a wide variety of low- to high-salinity environments (Keen 1990; Keen \& Racey, 1991), and also sometimes developing tubercles in low-salinity environments. These tubercles are generally indicative of less than 5 ppt salinity and are most common in juvenile instars. No such tubercles have been found among the four species discussed here. However, two species are found in lithologies indicating evaporitic conditions, and a third occurs at the close of the Eocene Epoch, which was a period of regression.

In the Sulaiman Range, $N$. simplex and $N$. regularis are confined to the gypsiferous shales known locally as Shales with Alabaster, uppermost member of the Ghazij Formation, upper Lower Eocene (Fig. 2).

Both these species occur in the Zao River section with such marine ostracod genera as Bairdia, Cytherella, Paracypris, Uroleberis, Xestoleberis, and, the most abundant of them all, the opportunistic Stigmatocythere obliqua Siddiqui 1971, which flourished in this environment.

In the Rakhi Nala section, $N$. regularis and $S$. obliqua thrived together, $S$. obliqua being again the more abundant; this situation is very similar to the one described by Keen \& Racey (1991) from the Lower Eocene, Rusayl Shale of Oman. $N$. simplex occurs at lower horizons in the Rakhi Nala, with a marine assemblage similar to that of the Zao River but also including Alocopocythere, Eucytherura, Cytherura, Phalcocythere and Schizoptocythere; Stigmatocythere obliqua is sparse at first but increases towards the top of the range.

$N$. simplex occurs with a marine assemblage in the Shpalai Khwara section.

This distribution suggests shallow marine shelf conditions where gypsiferous sediments were deposited in an evaporitic environment.

$N$. formosa occurs in the regression phase at the close of the Eocene Epoch in this area. It is found with marine genera including Acanthocythereis, Alocopocythere, Bairdia, Cytherella, Cytherelloidea, Krithe, Neomonoceratina, and Pterygocythere in the upper part of the Upper Chocolate Clays. This ostracod assemblage indicates an open shelf, fully marine, environment.

\section{STRATIGRAPHIC OCCURRENCE}

The oldest species of this genus recorded from Pakistan is 
Neocyprideis sp. A, from the Upper Palaeocene of the Sor Range section (Fig. 2). Neocyprideis simplex sp. nov. (Neocyprideis $\mathrm{sp}$. B, Siddiqui 1971) occurs in the Shales with Alabaster in the upper part of the Lower Eocene of the Rakhi Nala, Zao River, and Shpalai Khwara sections of the Sulaiman Range. Neocyprideis regularis sp. nov. (Neocyprideis $\mathrm{sp.} \mathrm{C,} \mathrm{Siddiqui} \mathrm{1971)} \mathrm{also}$ occurs at the top of the Shales with Alabaster, but only after $N$. simplex has disappeared. It is not represented in the Shpalai Khwara section. Neocyprideis formosa sp. nov. (Neocyprideis sp. D, Siddiqui 1971) occurs in the upper part of the Upper Chocolate Clays, uppermost Eocene of both the Rakhi Nala and Zao River sections. All of the new species appear to be good stratigraphic markers in this area.

\section{ACKNOWLEDGEMENTS}

This research was aided by a grant from Saint Mary's University Senate. SEM photomicrographs were made by David B. O'Neil, National Research Council Laboratories. Ursula Grigg prepared the text and Randy Corney prepared plates and figures. Dr. Renée Damotte (Université Pierre et Marie Curie, Paris) kindly reviewed the manuscript.

\section{Manuscript received 10 June 1997 \\ Manuscript accepted 28 February 2000}

\section{REFERENCES}

Apostolescu, V. 1956. Contribution à l'étude des ostracodes de l'Eocene inférieur (s.1.) du Bassin de Paris. Revue Institut Française de Petroles, Paris, 11: 1327-1352.
Eames, F. E. 1952. A contribution to the study of the Eocene in western Pakistan and western India. The geology of standard sections in the western Punjab and in the Kohat district. Quarterly Journal of the Geological Society of London, 107: 159-171.

Keen, M. C. 1990. The ecology and evolution of the Palaeogene ostracod Neocyprideis. Cour. Forsch. Inst. Senckenberg, 123: 217-228.

Keen, M. C. \& Racey, A. 1991. Lower Eocene ostracods from the Rusayl Shale Formation of Oman. Journal of Micropalaeontology, 10: 227-233.

Khosla, S. C. 1972. Ostracodes from the Eocene beds of Rajasthan, India. Micropaleontology, 18: 476-507.

Khosla, S. C. 1988. Tertiary and Recent species of Miocyprideis from India. In Hanai, T., Ikeya, N. \& Ishizaki, K. (Eds.), Evolutionary Biology of Ostracoda, Kodansha, Elsevier: 93-103.

Moore, R. C. (Ed.) 1961. Treatise on Invertebrate Paleontology: Q, Arthropoda 3, Geological Society of America, University of Kansas Press.

Oertli, H. J. (Ed.), 1985. Atlas des Ostracodes de France. Bulletin Centres Recherches Exploration Production Elf-Aquitaine, Memoire 9.

Siddiqui, Q. A. 1971. Early Tertiary Ostracoda of the family Trachyleberididae from West Pakistan. Bulletin of the British Museum, Natural History (Geology), Suppl. 9: 1-98.

Siddiqui, Q. A. 1981. Some species of the genus Schizocythere from the early Tertiary shelf sea of Pakistan. In Neale, J. W. \& Brasier, M. D. (Eds.), Microfossils from Recent and Fossil Shelf Seas. Ellis Horwood, Chichester: 231-239.

Siddiqui, Q. A. \& Al-Furaih, A. A. F. 1981. A new trachyleberid ostracod genus from the early Tertiary of western Asia. Palaeontology, 24: $877-890$

Singh, S. N. \& Misra, P. C. 1968. New genus and species of ostracodes from Fuller's Earth, Kolayatji, Bikaner, Rajusthan, India. Journal of the Palaeontological Society of India, 11: 26-37.

van Morkhoven, F. P. C. M. 1963. Post-Palaeozoic Ostracoda, Vol. II. Elsevier. 